\title{
Social-and-Ecological Aspects of Forage Production Reform in Ukraine in the Early $21^{\text {st }}$ Century
}

\author{
By V. Puyu ${ }^{1}$, M. Bakhmat ${ }^{1}$, H. Pantsyreva ${ }^{2}$, Y. Khmelianchyshyn ${ }^{1}$, \\ V.Stepanchenko ${ }^{1}$, O. Bakhmat ${ }^{1}$
}

\begin{abstract}
On the basis of the "three sigma" rule, a statistical stratification of the Ukrainian effective community into economic welfare groups according to their social and economic status has been carried out, thus creating the basis for substantiating the expediency of reforming the forage production sector in order to further expand the production of organic livestock products through the up-to-date approaches to the formation and use of climate adaptive feed-related phytocenoses. In order to increase the productivity of grass fodder, an innovative model of the grass-grazing complex has been developed. Its structure includes a cyclic wedge of long-term cereal-bean pasture which involves perennial grasses of the botanical species adapted to the zonal ecological and technological conditions, a satellite wedge of traditional mixtures of annual crops and atypical pasture plants - burnet polygamous (Poterium poligamum Woldst. et Kit.), prairie dock (Silphium perfoliatum L.) and others, whose herbage is used during the off-season, when the main cyclic wedge is found to be low-yielding, as well as a sheltered base, equipped with outdoor hoppers and shelters designed to protect animals in bad weather. The introduction of meadows and pastures in the system of zonal fodder production will contribute to the improvement and stabilization of the production of cheap and adequately nutritious herbal feeds thus increasing the resource potential of the area.
\end{abstract}

Keywords: pasture complex; block diagram; cycle wedge; satellite area; sheltered base.

\section{Introduction}

In the history of Ukraine the second decade of the 21 st century is to be considered a starting point for modernization of science and education, the agricultural sector and other areas of public life; bringing them to the level of achievements of modern Western society, in particular, such countries as Germany, Great Britain, France, etc.

The use model (paradigm) in agriculture is a burning issue particularly in terms of justification of fodder production as a factor determining the relevance and feasibility of growing production of ecologically safe meat and dairy products and other animal farming products according to European standards.

The requirements for the production of organic livestock production in the EU and the detailed rules for the production of organic products of animal origin in Ukraine state that animals must have access to open air and free grazing. However, the state of domestic pastures does not fully meet the current requirements of fodder production. 


\section{Literature Review}

In today's conditions, fundamental and applied scientific research has deepened, in which the problems of greening of agriculture and fodder production are the subject of special attention of scientists. In particular, the works are devoted to the development of these issues Kaletnik, G., Mazur V.A., Honcaruk I., Pantsyreva H.V., Shevchuk O.A., Didur I.M., Bakhmat O.M. and others.

The purpose of the research was to establish the scientific and technological basis for reforming the feed industry towards further expansion of the production of inexpensive eco-friendly feeds of natural origin based on the improvement of the cultural pasture design for more efficient use of the resource potential of the Forest Steppe area.

The task of the paper is to: carry out a statistical grouping of the Ukrainian viable community by economic status, determine the utilization rate of pasture resource in the Western Forest Steppe, develop a functional model of pasture complex which is able to stabilize the infestation of herbivores and antimalarial influences.

\section{Mythology}

The statistical grouping of the socially viable part of the population of Ukraine was carried out by the socio-property level by applying the rule of "three sigmas" in the number of the general population - approximately 20 million people.

Experimental basis for the development of a functional model of the pasture-grassland complex is the standard cultivated pasture of the Forest-Steppe of the West, which is a post-crop-rotation area with the herbage of cultivated perennial grasses. The utilization rate of the pasture resource in the Western Forest Steppe conditions is determined on the basis of the analysis of meteorological data 2005-2018, taking into account such natural anomalous phenomena as heavy rainfall, squall (hurricane) winds, heat waves, droughts and hailstorms.

\section{Case Studies}

In biology, the law of normal distribution suggested by Laplace-Gauss was realized by Lambert Adolphe Jacques Quetelet (Quetelet) (1796-1874), one of the most famous scientists - statistical biometricians of the $19^{\text {th }}$ century of Franco-Belgian origin. He found that such social phenomena as population, fertility, mortality, poverty, education, and trade; and natural such as climate, certain atmospheric disasters and others are primarily subject to the law of normal distribution.

According to L. A. Quetelet, every stochastic ("absolutely" randomized) numerical experimental matrix is graphically reproduced with a bell curve, if argument axis $(X)$ is divided into segments (classes) according to the "three sigma»: rule of $\mu \pm 1 \delta, \mu \pm 2 \delta, \mu \pm$ $3 \delta$, (classic version, other options are possible), and functional $-(Y)$ characterizes the class (group) density in relative terms, usually in percentage (Fig. 1). 


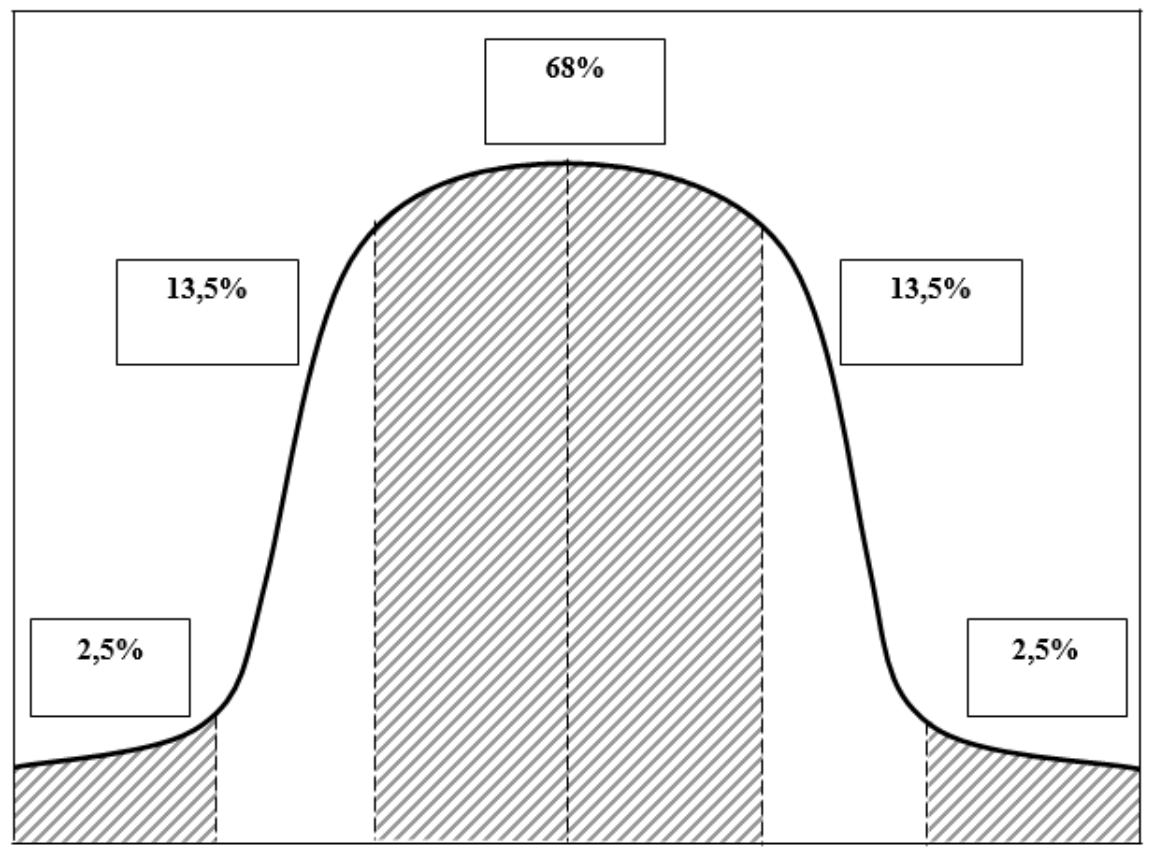

$$
\begin{array}{lllll}
\chi-2 \sigma & \chi-\sigma & \chi=M_{0}=M_{\sigma} & \chi+\sigma & \chi+2 \sigma
\end{array}
$$

Fig. 1. Model - in graphical format $(\min 0 \rightarrow \max \rightarrow \ldots \rightarrow \min 0)$

In the context of modern economic decentralization, the conditional-potential stratification of the Ukrainian community (with the total population of able-bodied population - approximately 20 million people) is characterized by functional content (Table 1).

Table 1. Statistical grouping of the socially efficient population of Ukraine according to their economic status in the "three sigma" format

\begin{tabular}{|l|c|c|c|}
\hline \multicolumn{2}{|c|}{ Economic welfare groups } & \multicolumn{2}{c|}{ Structure } \\
\hline Social rating & Statistical compliance $\mu \pm \delta$ & Mln people & $\%$ \\
\hline 1. Super super high & $>+3 \delta$ & 0,027 & 0,135 \\
\hline 2. Super high & $+3 \delta$ & 0,427 & 2,135 \\
\hline 3. High & $+2 \delta$ & 2,720 & 13,600 \\
\hline 4. Middle (+) & $+1 \delta$ & 6,226 & 31,130 \\
\hline 5. Middle (-) & $-1 \delta$ & 6,226 & 31,130 \\
\hline 6. Low & $-2 \delta$ & 2,720 & 13,600 \\
\hline 7. Super low & $-3 \delta$ & 0,427 & 2,135 \\
\hline 8. Super super low & $<-3 \delta$ & 0,027 & 0,135 \\
\hline Total & $\pm 3 \delta$ & 20 & 100 \\
\hline
\end{tabular}

The statistical grouping method helps to theoretically describe a potential option of the 
class structure of Ukrainian community as to their social and property incomes as follows: 1. Oligarchs -0.45 million (No $1+$ No $2-2.3 \%$ ); 2 . affluent people -2.7 million (No 3 - 13.6\%); 3. electorate (middle class) - 12.4 million (No $4+$ No $5-62.3 \%$ ); 4. Les Miserables (poor) -2.7 million (No $6-13.6 \%$ ); 5 . Homeless and so on -0.45 million (No $7+$ No $8-2.3 \%)$.

The division of the population by property and wealth into groups makes it possible to roughly determine the marketability of livestock production and domestic sources of investment resource, namely: one hundred percent organic (15.9\% (for all environmental, sanitary and technological parameters; for the first two social groups), conditionally organic $-63.2 \%$ (for the third group) and surrogate different quality levels $-15.9 \%$ (for the fourth and fifth groups).

Based on the social (class) Model of the $20^{\text {th }}$ century, division of the population was fundamentally different and, consequently, $85-90 \%$ of the food market was supplied by domestic products at the expense of state budget sources. Today, except for grain, sugar and oil food groups, all the food products are mainly of foreign origin (apples are imported from Poland, Greece, Italy, Spain; onion and garlic - from China, the Netherlands, Poland, Slovenia; carrots are supplied by Israel, China, Turkey; tomatoes, cucumbers are imported from Turkey, Spain, Greece, the Netherlands, Poland, Syria; potatoes - from the Netherlands, Egypt, Poland, Hungary, Czech Republic, and Russia). The dairy market is in a much more dire state as there are negative trends in the further decline in productive cattle production.

The class of representatives of monopolistic, industrial and financial capital, as an objective social phenomenon, does not arise and does not disappear due to its existence under the natural laws of planetary evolution. Therefore, not taking into account the current argument in the reform of commodity markets is economic nonsense.

Neglect of the social stratification and requirements of society and concentration on a single, universal type market is the foundation of economic crises, these can be domestic, European, American, and global.

The basic principles of organic (biological) agriculture as a means of improving the quality of food were first widely announced by academician I. S. Shatilov. That happened more than 3 decades ago, but the problem has not lost its relevance, on the contrary, it is even more acute.

For livestock production without GMOs, competition for natural (forest pasture) conditions, one has to change the philosophy and attitude and radically reform the forage base. The dominant fodder fields must be of natural pasture type, such as the American prairies, alpine and subalpine meadows, Crimean jajl, and Carpathian Valleys.

An expanded Modelatic model was first suggested by the author at a seminar of crop and fodder experts from Ukraine and other countries devoted to: "Varietal technologies as a factor in the implementation of biopotential of agrocenoses in the yield programming system for field and forage crops" (Uman NUS, 15-16 May 2014), as a presentation report: "Innovative model of cultural pastures as a means of producing environmentally friendly animal farming products" and it was recognized as invention under application No 2008 08596 of 01.07.2008; Patent - № 40618 of 27.04.2009 (Fig. 2). 


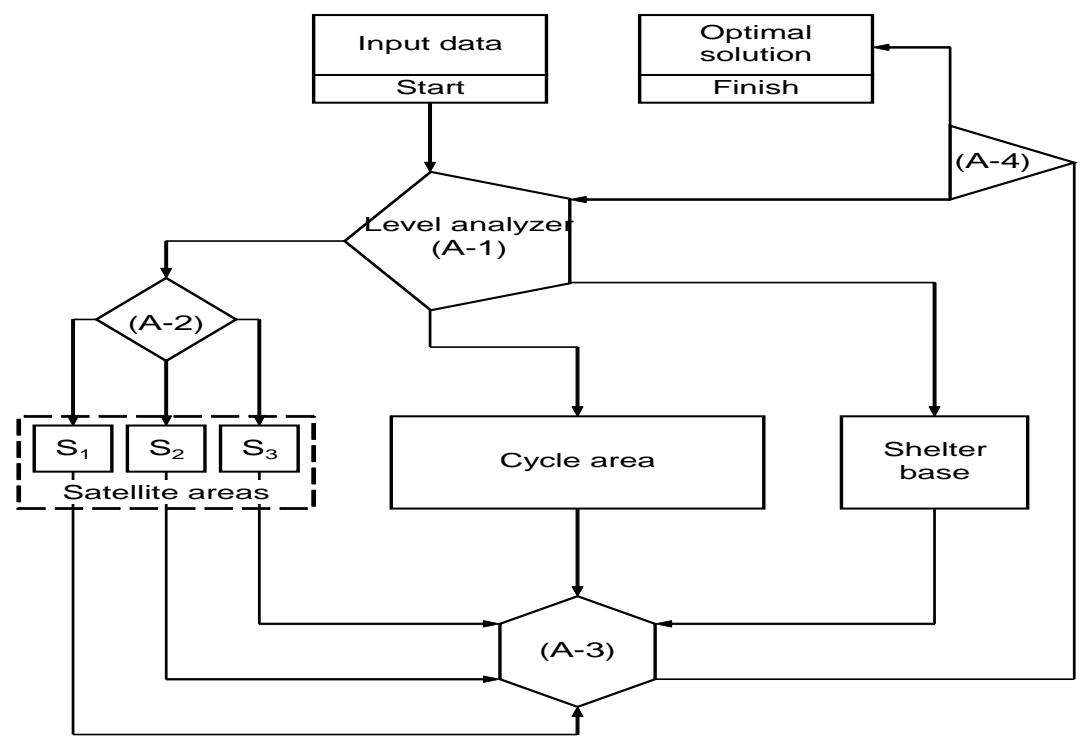

Fig. 2. Block diagram of pasture complex (functional).

A standard cultural pasture was selected as an experimental base for the invention. It was represented by an after sowing change area of perennial grasses suitable for grazing cattle (mostly cows) during the growing season of $160 \ldots 200$ days.

The value of a cultivated pasture as a forage field is that it is the main source of functional eco-friendly cow feed that provides high quality milk. No other food was competitive compared to grass-juicy green pasture.

The downside of modern cultural pastures is the inability to use them in rainy days, and those account for up to 22 days (18\% of the active grazing period); other weather issues approximately account for another 12 days (9.8\%). In total, $27.9 \%$ of the active grazing period in terms of Western Forest Steppe was beyond the period of productive use.

We estimate the efficiency of use of pasture resources $=0.72$ (with $\lim =0,36 ; 0,57$ (June) to 0.93 (September) (Table. 2).

Table 2. Changes in the Grazing Resource Utilization Ratio (GRUR) depending on natural anomalous phenomena in the Western Forest Steppe (average for 2005-2018)

\begin{tabular}{|l|c|c|c|c|c|c|}
\hline \multirow{2}{*}{ Natural phenomenon } & Accounting & \multicolumn{3}{|c|}{ Month } & of year & $\sum$ \\
\cline { 3 - 7 } & index & 06 & 07 & 08 & 09 & $06-09$ \\
\hline 1. Rainfall or storm weather \\
of preventive nature & Days & 10 & 6 & 4 & 2 & 22 \\
\hline \multirow{2}{*}{ 2. Stormy (hurricane) winds } & $\%$ to $S t$ & 33,3 & 19,4 & 12,9 & 6,7 & 18,0 \\
\hline \multirow{2}{*}{ 3. Others (heat, heatwave, hale and others) } & days & 2 & 3 & 1 & 0 & 6 \\
\cline { 2 - 7 } & $\%$ AO $S t$ & 6,7 & 9,7 & 3,2 & 0 & 4,9 \\
\cline { 2 - 7 } & days & 1 & 2 & 3 & 0 & 6 \\
\hline \multirow{2}{*}{ Total } & doys $S t$ & 3,3 & 6,5 & 9,7 & 0 & 4,9 \\
\hline GRUR coefficient & $\%$ to $S t$ & 43,3 & 35,5 & 25,8 & 6,7 & 27,9 \\
\hline Base $(S t)-$ natural pasture resource & $30+31+31+30=122$ days $(100 \%)$ \\
\hline
\end{tabular}


The invention is tasked to improve the design of cultural pastures in order to ensure full use of the resource potential of the territory at the $90-100 \%$ level.

Its essence is that the grazing area includes two feed wedges (one in the standard version): a wedge of the standard type perennial grass mixtures (cyclic) and wedge named satellite where atypical perennial plants such as prairie dock, artichoke, burnet polygamous etc. grow together with annual grass mixtures suitable for short-term grazing.

The combination of cyclical and satellite areas precludes recurrence of no grass off-season situations. A shelter base equipped with the necessary protective structures and racks for fresh pasture mass is provided for the period of short-term bad weather conditions. In the major variant the shelter base can serve as a summer range for the animals and release of the livestock winter premises during the grazing season.

The design of the cultural pasture provides for an area with standard botanical mixed perennial grasses for grazing animals, characterized by the fact that a supporting area with atypical pasture plants is attached to the main one. They become grazing forage on condition that grasses of the cycle area burn out, and a shelter area is also provided to protect and feed animals during periods of bad weather.

The flowchart of the pasture complex (Fig. 2) is suitable as a model for computer programming. It involves the perception of experimental output data (start) and issuing an optimal solution (end). Output data include livestock rations, fodder plan, stock feed, forage crops sowing area and others. They are fed to the first level analyzer. A computer program transfers information about the processed output data to the second level analyzer, which is related to satellite areas, cycle area and shelter base. All data from these components interact with analyzer No 3, and after electronic processing of the operational information are transferred to analyzer No 4. Prompt optimal solution based on analysis of the relevant material are taken.

The suggested model operates as an innovative element and is a structural part of the organizational and farming practices designed to improve quantitative and qualitative indicators of pastures.

Thus, to provide animals with complete feed of natural origin, and the population with environmentally friendly food products of animal origin it is advisable to implement our functional model which is recognized by the national scientific community and is suitable for practical implementation in the system of livestock industry reform.

\section{Discussion and Conclusions}

Division of the population by property and wealth criteria into groups makes it possible to roughly determine the marketability of livestock production and domestic sources of investment resource. Thus, $100 \%$ organic products will be intended for representatives with a high level of security; conditionally organic for those with an average level of security and different quality surrogates for the poor and socially disadvantaged. The modern design of the cultural pasture should include two forage wedges - a cycle wedge with climate adaptive perennial grasses and a satellite wedge from the insurance area with traditional mixtures of annual crops and cultures which are not typical for pastures - prairie dock, Jerusalem artichoke, burnet polygamous, etc. whose herbage is used in the off-season, when the main cycle wedge shows low productivity. Rainy days use 
a sheltered base, equipped with protective structures and feeders.

Introduction of a pasture complex that can withstand the negative effects of natural anomalous phenomena, will help stabilize the conveyor production of grass feed and increase the resource potential of the area.

\section{References}

Naum Raichesberg (2000). Adolphe Quetelet, His Life and Research Activities. Moscow: Elibron Classics, 2000. 98 p.

Mazur V.A., Pantsyreva H.V., Mazur K.V., Myalkovsky R.O., Alekseev O.O. Agroecological prospects of using corn hybrids for biogas production. Agronomy Research 18(1), 177-182, 2020.

Shatilov I. S., Chudnovskyi A. F. (1980). Agrophysical, Agrometeorological and Agrotehnical Crop Programming Fundamentals: ACS of TP Principles in Land Cultivation. Leningrad: Gidrometeoizdat, $1980.320 \mathrm{p}$.

Begey S. V., Shuvar I. A. (2007). Ecological Agriculture: Textbook. Lviv: Novyi Svit-2000. 429 p.

Environmental Problems of Agriculture: Tutorial: V. P. Gudz, M. F. Rybak, S. P. Tanchyk et al.; Ed. V. Gudz. Zhytomyr National Agroecological University Press, 2010. 708 p.

Environmental Issues of Agriculture / I. D. Prymak, Y. P. Manko, N. M. Ridey et al.; Ed. I. D. Primak. Kyiv: Center of Educational Literature, 2010. 456 p.

Puyu V. L., Bakhmat M. I., Rykhlivskyi I. P., Shcherbatiuk N. V. (2019). Optimization of Conveyor Production of Green Fodder. World Science. No 7 (47). Vol. 1. doi: 10.31435/rsglobal_ws/31072019/6587.

Puyu V. L. (2014). Modern Design of Cultivated Pastures in the Western Forest Steppe. Seminar Program of Uman NUS "Varietal Technologies as a Factor in the Implementation of Agrocenoses Biopotentials in the Programming System of Field and Forage Crops Yield". Uman, 15-16 May 2014.

Mazur, V.A., Branitskyi, Y.Y., Pantsyreva, H.V.(2020). Bioenergy and economic efficiency technological methods growing of switchgrass. Ukrainian Journal of Ecology, 10(2), 8-15.

Cultural Pasture: Patent No 40618 / V. L. Puyu, M. I. Bakhmat, S. A. Tsvigun; Podillya State Agrarian Engineering University, UA. Application dated 01.07.2008; published 27.04.2009. Industrial Property. Kyiv, 2009. Bulletin No 8.

Bandura V., Mazur V., Yaroshenko L., Rubanenko O. Research on sunflower seeds drying process in a monolayer tray vibration dryer based on infrared radiation. INMATEN - Agricultural Engineering, vol. 57, №1, 2019. P. 233-242

Bransby D. I. Compatibility of switchgrass as an energy crop in farming systems of the southeastern USA. D. I. Bransby, R. Rodriguez-Kabana,

Ermakov, A., Arasymovych, V., Yarosh, N. et al. 1987. Methods Studies biochemically plants. L.: Agropromizdat, P. 430.

G. A. Esbroeck, M. A. Hussey, M. A. Sanderson. Crop Sci, 1997. No. 37. P. 864-870.

Ishchenko, V. Belyakov, A. 2009. Efficiency of micronutrients, growth regulator and ryzohuminu in increasing productivity varieties of peas without leaves type. Steppe Bulletin. 6:37-41.

Kolesnik, S. 2012. Bacterial fertilizer to optimize nitrogen and phosphorus nutrition soybeans, chickpeas, peas, lentils and commit. Feed and fodder. 73:145-151.

Ma Z. Impact of row spacing, nitrogen rate, and time on carbon partitioning of switchgrass Z. Ma, C. W. Wood, D. I. Bransby. Biomass Bioenergy, 2001. No. 20. P. 413-419. 16.

Malchevskaya, E., Mylenkaya, G. 1981. The comments and Animal Husbandry quality forage analysis. Minsk . Harvest, P. 143.

Mazur, V. A., Myalkovsky, R.O., Mazur, K. V., Pantsyreva, H. V., Alekseev, O.O. (2019 Influence of the Photosynthetic Productivity and Seed Productivity of White Lupine Plants. Ukrainian Journal of Ecology, 9(4), 665-670.

Mazur, V.A., Didur, I.M., Pantsyreva, H.V., \& Telekalo, N.V. (2018). Energy-economic efficiency of graincrop cultures in the conditions of the right-bank Forest-Steppe of Ukraine. Ukrainian J Ecol, 8(4), 26-33. 
Mazur, V.A., Pantsyreva, H.V., Mazur, K.V. \& Didur, I.M., (2019). Influence of the assimilation apparatus and productivity of white lupine plants. Agronomy research. 17(1), 206-219.

Melnychuk, T., Patyka, V. 2011. Microbial preparations bioorganic farming system. Collected articles "Third All-Ukrainian Congress of Ecologists with international participation." Vinnytsya. Tom.2: 423-426.

Muir J. P. Biomass production of Alamo switchgrass in response to nitrogen, phosphorus, and row spacing. J. P. Muir, M. A. Sanderson, W. R. Ocumpaugh at all. Agron J., 2001. No 93. P. 896-901.

Ovcharuk V.I., Mulyarchuk O.I., Myalkovsky R.O., Bezvikonnyi P.V., Kravchenko V.S., Klymoych N.M. Parameters of beet plants. Bulletin of the Uman National University of Horticulture. 2019. № 1. P. 70-75.

Pantsyreva H.V. (2018). Research on varietal resources of herbaceous species of Paeonia L. in Ukraine. Scientific Bulletin of the NLTU of Ukraine, 28 (8), 74-78. https://doi.org/10.15421/40280815

Pantsyreva, H.V. (2019). Morphological and ecological-biological evaluation of the decorative species of the genus Lupinus L.. Ukrainian Journal of Ecology, 9(3), 74-77.

Pantsyreva, H.V. (2019). Morphological and ecological-biological evaluation of the decorative species of the genus Lupinus L.. Ukrainian Journal of Ecology, 9(3), 74-77.

Pantsyreva, H.V. Technological aspects of biogas production from organic raw materials. Bulletin of KhNTUSG them. P. Vasilenko. Kharkiv, 2019. P. 276-290.

S. E. Sladden. Biomass Conf. of the Americas. Burlington, 1993. P.229-234.

Mazur V.A., Mazur K.V., Pantsyreva H.V., Alekseev O.O. Ecological and economic evaluation of varietal resources Lupinus albus L. in Ukraine Ukrainian Journal of Ecology. 2018. Volume 8.148-153.

V.G. Kuryata, S.V. Polyvanyi, O.A. Shevchuk, O. Tkachuk. 2019. Morphogenesis and the effectiveness of the production process of oil poppy under the complex action of retardant chlormequat chloride and growth stimulant treptolem. Ukrainian Journal of Ecology. 9 (1). 127-134.

Vdovenko, S.A., Pantsyreva, G.V., Palamarchuk, I.I., \& Lytvyniuk, H.V. (2018). Symbiotic potential of snap beans (Phaseolus vulgaris L.) depending on biological products in agrocoenosis of the right-bank forest-steppe of Ukraine. Ukrainian J Ecol, 8(3), 270-274.

Vdovenko, S.A., Prokopchuk, V.M., Palamarchuk, I.I., \& Pantsyreva, H.V. (2018). Effectiveness of the application of soil milling in the growing of the squash (Cucurbita pepo var. giraumontia) in the right-benk forest stepp of Ukraine. Ukrainian J Ecol, 8(4), 1-5.

Vitalii Palamarchuk, Inna Honcharuk, Tetiana Honcharuk, Natalia Telekalo. Effect of the elements of corn cultivation technology on bioethanol production under conditions of the right- bank forest-steppe of Ukraine. Ukrainian Journal of Ecology. 2018. №8(3). 47-53.

O.A. Shevchuk,.O. Tkachuk, V.G. Kuryata,O.O. Khodanitska, S.V. Polyvanyi. 2019. Features of leaf photos ynthetic apparatus of sugar beet under retardants treatment. Ukrainian Journal of Ecology. 2019. 9 (1). P. 115-120.

O.O. Khodanitska, V. G. Kuryata, O.A. Shevchuk, O.O. Tkachuk, I.V. Poprotska. 2019. Effect of treptole $\underline{m}$ on morphogenesis and productivity of lin seed plants. Ukrainian Journal of Ecology. 9 (2). 9126.

Kaletnik G.M., Zabolotnyi, G.M. Kozlovskyi S.V (2011), "Innovative models of strategic management economic potential within contemporary economic systems", Actual Problems of Economics, vol, 4(118), pp. -11.

Yanovych, V., Honcharuk, T., Honcharuk, I. \& Kovalova, K. (2017). Design of the system to control a vibratory machine for mixing loose materials. Eastern-European Journal of Enterprise Technologies, 6(3-90), 4-13.

Yanovych, V., Honcharuk, T., Honcharuk, I. \& Kovalova, K. (2018). Engineering management of vibrating machines for targeted mechanical activation of premix components. INMATEH - Agricultural Engineering, 54(1), 25-32.

Palamarchuk, V., Telekalo, N. (2018). The effect of seed size and seeding depth on the components of maize yield structure. Bulgarian Journal of Agricultural Science, 24(5), 2018. 785-792.

Kaletnik, G., \& Lutkovska, S. (2020). Innovative Environmental Strategy for Sustainable Development. European Journal of Sustainable Development, 9(2), 89. https://doi.org/10.14207/ejsd.2020.v9n2p89 